\title{
Effect of salting and ripening on the physicochemical and sensory quality of goat and sheep cured legs
}

\author{
Alfredo Teixeira ${ }^{\mathrm{a}, \mathrm{c}, *}$, Aline Fernandes ${ }^{\mathrm{c}}$, Etelvina Pereira ${ }^{\mathrm{c}}$, Aristides Manuel ${ }^{\mathrm{c}}$, Sandra Rodrigues ${ }^{\mathrm{b}, \mathrm{c}}$ \\ a Veterinary and Animal Research Centre (CECAV), Portugal \\ b Mountain Research Centre (CIMO), Portugal \\ c Escola Superior Agrária/Instituto Politécnico de Bragança, Campus de Santa Apolónia, 5300-253 Bragança, Portugal
}

\section{A R T I C L E I N F O}

\section{Keywords:}

Sheep

Goat

Cured legs

Chemical composition

Fatty acids profile

\begin{abstract}
A B S T R A C T
Physicochemical and sensory characteristics of sheep and goat cured legs were evaluated. The pH values (5.7-5.8) and aw (0.87 and 0.83 ) found to be adequate to control meat deterioration, promoting safety and stability to shelf life of products with respect to microbial growth. The high protein (46.2 and 38.4\%) and low fat (5.3 and 8.7\%) percentages of the goat and sheep cured legs were the main evidence of the effect of salting and ripening processes. A low cholesterol content of $4.5 \%$ is particularly evident in sheep cured legs. Curing process produced a slight increase in the $\mathrm{P} / \mathrm{S}$ ratio 0.23 and 0.17 for goat and sheep cured legs, respectively. TBARS values are much lower than the value of $2 \mathrm{mg}$ of MDA/Kg which is the upper limit of rancidity. Physico-chemical and sensory characteristics indicate that producing cured goat and sheep legs from cull animals can be an interesting way of adding value to animals with very low commercial prices.
\end{abstract}

\section{Introduction}

Goats and sheep are one of the most important sources of meat produced and one of the most popular consumed in world. About $70 \%$ of world's population consumes sheep and goat meat as part of their regular diet and in several countries are the main products of traditional dishes. Also in countries which are not considered as goat or sheep consumers more and more goat and sheep meat is being consumed and consequently the different agents involved in meat industry become more interested in the control of production in terms of quality and food safety. The most consumed are cabrito from goats and cordeiro from sheep (meat from milk fed animals with no $>3$ months age and 5 to $8 \mathrm{~kg}$ carcass weight) or chivo and lamb, from goats and sheep respectively (animals with 6 to 9 months age with $>11 \mathrm{~kg}$ carcass weight). Most of them are commercialized as brands under Protected Origin Designation (PDO) or Protected Geographical Indication (PGI). Meat from older animals particularly the culled ones are not so popular but are also consumed in several countries as processed meats. This meat from animals with very low commercial value is more appropriated to process and cure with salts as some of popular products as Cecina in Spain (Hierro, de la Hoz, \& Ordoñez, 2004), or Brazilian Charqui (Madruga \& Bressan, 2011) ore in Italy violin di capra (Fratianni, Sada, Orlando, \& Nazzaro, 2008). Also with the goal to added value to depreciated meats several authors have recently studied sheep and goat processed products as Polpara, Sornprasitt, and Wattanachant (2008) studying quality characteristics of raw and canned goat meat during storage in water, brine, oil and Thay curry; Das, Anjaneyulu, Thomas, and Kondaiah (2009) studying the effect of different fats on the quality of goat meat patties; Teixeira, Pereira, and Rodrigues (2011) evaluating the effect of salting, air-drying and aging in a new goat meat product "manta"; Oliveira et al. (2014) analyzing the quality of ewe and goat meat cured products; Leite et al. (2015) and Paulos et al. (2015) studying the properties of sheep and goat meat sausages and Tolentino, Estevinho, Pascoal, Rodrigues, and Teixeira (2016) evaluating the microbiological and sensory quality of new meat cured products obtained from sheep and goat meat of culled animals. In this context, a project among a research center (Carcass and Meat Quality and Technology Laboratory of Agriculture Scholl of Polytechnic Institute of Bragança), two breeder associations (ANCRAS - National Breed Producers Association of Serrana Goat and ACOB - National Breed Producers Association of Bragançana Sheep) and a meat manufacturing industry and Bísaro breed producer (Bísaro Salsicharia Tradicional) was developed to add value to animals with very low commercial value and consumer acceptability, processing meat that cannot be commercialized as PDO or IGP products. The aim of this work was to describe the physicochemical and sensory characteristics sheep and goat cured legs.

\footnotetext{
* Corresponding author at: Veterinary and Animal Research Centre (CECAV), Portugal.

E-mail address: teixeira@ipb.pt (A. Teixeira).
} 


\section{Material and methods}

\subsection{Animals and sampling}

Fifty-one animals were used, 27 ewes of Churra Galega Bragançana breed and 24 goats of Serrana breed, between 8 and 12 years old with $20.0 \pm 1.9 \mathrm{~kg}$ of carcass weight. Animals were from commercial flocks reared under an extensive system and were selected by the National Breeders Associations. Animals were slaughter in the official slaughterhouse of Bragança in three different times. After slaughter, carcasses were cooled at $4 \pm 1{ }^{\circ} \mathrm{C}$ for an aging period of 7 days. Later, carcasses were divided into quarters and legs from the right part of the carcass, weighing $\sim 3 \mathrm{~kg}$ were removed by cutting perpendicularly through the vertebral column near the anterior part of the ilium process and were identified. Fabrication process was made at LTQCC (Carcass and Meat Quality and Technology Laboratory of Agriculture Scholl of Bragança) once and twice at Bísaro Salsicharia Tradicional. The fabrication process consisted in the following phases: salting: legs were dry-salted with coarse marine salt forming piles completely covered with a $5 \mathrm{~mm}$ of salt layer, over a perforated trays (with outflow, allowing the liquid salt to exit) in a salting room (temperature between 2 and $5{ }^{\circ} \mathrm{C}$ and a relative humidity of 80 to $90 \%$ ) during a period corresponding to 1 day of salting for each $1 \mathrm{~kg}$ of the piece; Cleaning and washing: legs were washed and cleaned removing the salt with a brush and hanging in a refrigerated room (temperature $4 \pm 1{ }^{\circ} \mathrm{C}$ ) during 1 day to stabilized; Curing and drying: legs were rubbed with mixture of olive oil, garlic and red chilli paste and handling covering each piece with an anti-fly net in a air-dried room with a controlled temperature $\left(8-10{ }^{\circ} \mathrm{C}\right)$ and relative humidity of $60-70 \%$ for 1 to 2 months; Ripening: legs were ripened during 7 to 8 months in a room with a temperature between 17 and $20{ }^{\circ} \mathrm{C}$ and relative humidity of $60-70 \%$.

For each 3 lots fabricated in three different times ( 3 replications) 8 and 9 (repetitions) goat and sheep legs, respectively were analyzed twice, for a total of 104 samples ( 3 replications $\times 8$ and 9 legs $\times 2$ analysis).

\subsection{Physicochemical analysis}

Before fabrication meat samples of legs from the left side of carcasses samples were chemistry analyzed corresponding to raw product composition. All samples included portions of M. Biceps femoris, M. Semitendinosus and M. semimembranosus. Physical analyses of samples of cured legs were made at the end of each fabrication process specifically at slaughter, salting and ripening. Chemical analyses were made at slaughter as raw material and in the final product at the end of ripening.

The measurement of $\mathrm{pH}$ was performed according to the Portuguese standard NP 3441 (2008) using a potentiometer with an electrode equipped with a penetrator cell calibrated with standard buffers with the $\mathrm{pH} 4,01-7$ and 02 . Water activity was assessed with an $\mathrm{a}_{\mathrm{w}}$ probe (HygroPalm Aw1 rotronic 8303, Basserdorf, Switzerland) according to AOAC (1990). Moisture content determination was carried out following the Portuguese standard NP 1614 (2002) based on ISO 1442:1197.

Meat color was estimated on the semimembranosus muscle using the lightness $\left(\mathrm{L}^{*}\right)$, redness $\left(\mathrm{a}^{*}\right)$, and yellowness $\left(\mathrm{b}^{*}\right)$ system with a colorimeter Minolta CR-10 (Minolta, Osaka, Japan). This system of color was described with the coordinates $\mathrm{L}^{*} \mathrm{a}^{*} \mathrm{~b}^{*}$ (CIE, 1986). Color measurements were made on cut surfaces at the end of ripening process. Determination of hue $\left(\mathrm{H}^{*}\right)$ and chroma $\left(\mathrm{C}^{*}\right)$ attributes was made according to the following equations:

$\mathrm{H}^{*}=\arctan \left(\mathrm{b}^{*} / \mathrm{a}^{*}\right) ;$ and $\mathrm{C}^{*}=\sqrt{ }\left(\mathrm{a}^{*}\right)^{2}+\left(\mathrm{b}^{*}\right)^{2} \times 57.29$ and expressed in degrees.

The determination of the chloride content was performed according to NP 1845 (1982). For the titration the Titrino Plus brand was used with $0.1 \mathrm{~N}$ silver nitrate solution (AgNO3). When the value of P1 is found by the equipment it means that the titration is complete. The chloride content $(\mathrm{NaCl})$ of the sample being expressed as a percentage, by mass by the equipment itself.

Protein content was evaluated following the Portuguese standard NP 1612 (2002) using a Kjeldahl System equipment a gas neutralizer Buchi K-415 coupled to the Buchi K-446 Mineralizer and a Buchi auto Kjeldahl Unit K-370 distiller.

The Hydroxyproline Determination of Collagen Content and Concentration was determined following the Portuguese Standard NP 1987 (2002). The samples were hydrolysed with sulfuric acid (3 mol/L) in a Raypa greenhouse at $105^{\circ}$ for $16 \mathrm{~h}$. Subsequently the samples were removed, filtered and diluted to obtain the hydrolyzate. The hydrolyzate was oxidized by means of chloramine $\mathrm{T}$, then with the addition of p-demethylaminobenzide a yellow colored compound was formed. The samples were taken to the water bath for $20 \mathrm{~min}$, cooled and read in a Spectronic Unicam 20 Genesys (SPECTRONIC 20 GENESYS, Thermofisher Scientific, Austin, Texas, USA) at a wavelength of $558 \mathrm{~nm}$.

The cholesterol determination was carried out the procedure described by Domínguez, Crescente, Borrajo, Agregan, and Lorenzo (2015b) as follow: $2 \mathrm{~g}$ of meat sample was placed in a screw Teflonlined cap tube with $0.2 \mathrm{~g}$ L-ascorbic acid and $5 \mathrm{~mL}$ saponification solution $(11 \% \mathrm{w} / \mathrm{v}$ potassium hydroxide in a mixture of $55 \% \mathrm{~V} / \mathrm{V}$ absolute ethanol and $45 \% \mathrm{v} / \mathrm{v}$ distilled water) and was immediately vortexed; after the saponification reaction was placed in a shaking bath water at $85{ }^{\circ} \mathrm{C}$ during $45 \mathrm{~min}$.; then the samples were cooled and was added $1.5 \mathrm{~mL}$ of distilled water and $3 \mathrm{~mL}$ of $25 \mu \mathrm{g} / \mathrm{mL}$ HHT solution in $\mathrm{n}$-hexane. Then the samples were vortexed and a centrifuged at $1500 \times g$ for $5 \mathrm{~min}$, to accelerate the phase separation. An aliquot of the upper layer (n-hexane) was transferred to a screw teflon-lined a cap tube and added a spatletip of anhydrous sodium sulphate. Finally, the tube was shaken and an aliquot of the n-hexane layer was filtered through a $0.45 \mu \mathrm{m}$ hydrophobic membrane into an amber screw cap vial with teflon septum. Analysis of samples was carried out using a HPLCV Ultimate 3000, Thermo Scientific system from Dionex (Germany).

Lipid oxidation was determined following the Portuguese standard NP 3356 (2009). Thiobarbituric acid reactive substances (TBARs) index was measured using $50 \mathrm{~g}$ of sample dispersed in $5 \%$ trichloroacetic acid $(10 \mathrm{~mL})$ and in an Ultra-Turrax IKA ${ }^{\oplus} \mathrm{T} 25$ (Germany) for $2 \mathrm{~min}$. The homogenate was remained for $10 \mathrm{~min}$ at $10^{\circ} \mathrm{C}$ and after that centrifuged at $2360 \mathrm{~g}$ for $10 \mathrm{~min}$. The supernatant was filtered through a (VWR, France) No.516-0351 filter paper (particle retention: 12-15 $\mu \mathrm{m}$ and $5 \mathrm{~mL}$ of the filtrated was reacted with $5 \mathrm{~mL}$ of $0.02 \mathrm{M}$ thiobarbituric acic solution and incubated in a water bath for $40 \mathrm{~min}$. at $96{ }^{\circ} \mathrm{C}$. The absorbance was measured at $530 \mathrm{~nm}$ using a Genesys $10 \mathrm{~S}$ UV-VIS spectrophotometer (Made in China. Designed in USA). TBARS values were calculated from a malonaldehyde (MDA) standard curve with 1.1-1.3 tetraethoxypropane (TEP) and were expressed as mg MDA/kg sample.

Total lipids were extracted from $50 \mathrm{~g}$ of pâté sample according to the Folch, Lees, and Stanley (1957) procedure. Fifty milligrams of fat were used to determine the fatty acid profile. Fatty acid were transesterified according the procedure described by Domínguez, Borrajo, and Lorenzo (2015a) and as follow: $4 \mathrm{~mL}$ of a sodium methoxide (2\%) solution were added to the fat, vortexed every $5 \mathrm{~min}$ during $15 \mathrm{~min}$ at room temperature, then $4 \mathrm{~mL}$ of H2SO4: methanol solution (1:2), vortexed a few seconds and vortexed again before adding $2 \mathrm{~mL}$ of distilled water. Organic phase (containing fatty acids methyl esters) was extracted with $2.5 \mathrm{~mL}$ of hexane. Separation and quantification of the FAMEs were carried out using a gas chromotograph (Shimadzu GC2010 Plus with an Auto Injector AOC - 20i, Kyoto Japan) and using a Supelco ${ }^{\circledR}$ fused silica capillary column $(100 \mathrm{~m} \times 0.25 \mathrm{~mm} \times 0.2 \mu \mathrm{m}$ film thickness). The chromatographic conditions were as follows: initial column temperature $120^{\circ} \mathrm{C}$, maintaining this temperature for $5 \mathrm{~min}$, programmed to increase at a gradient of $15{ }^{\circ} \mathrm{C} / \mathrm{min}$ and the injector and detector were maintained at $280^{\circ} \mathrm{C}$. Nitrogen, Hydrogen and synthetic Air pure were used as the carrier gases and the tridecanoic acid 
$\left(\mathrm{C}_{13} \mathrm{H}_{26} \mathrm{O}_{2}\right)$ as internal standard was added to the samples prior methylation. FAMEs were identified comparing their retention times with those of authenticated standards (Supelco 37 Component FAME Mix). Data were expressed in $\mathrm{g} / 100 \mathrm{~g}$ of fat.

\subsection{Sensory analysis}

For the sensorial evaluation of the cured sheep and goats' legs a semi-trained taste panel and a consumers' panel were constituted.

For both taste and consumers panels, samples were prepared so as to use small pieces removed from the same anatomical site, which were cleaned (removing the exposed outer parts), vacuum packed and refrigerated, for later presentation to the panelists. To perform the tests, the pieces were thawed the day before, in refrigeration chambers at a temperature of $4{ }^{\circ} \mathrm{C}$. Subsequently, the samples were duly cut into small slices, with a thickness of $0.2 \mathrm{~mm}$ (millimeters), and packed in foil, being randomly coded with two numbers followed by a letter, in order to prevent any kind of influence.

The taste panel in this study was composed by experienced 10 testers for their participation in previous research. The members of the group were professors and other employees of the Polytechnic Institute of Bragança. This way, recruitment and selection phases were exceeded. However, training sessions were conducted prior to the evaluation sessions, for adaptation to the cured sheep and goat legs and their specific attributes. The whole process of forming the panel obeyed the Portuguese Standard (NP-ISO-8586-1, 2001).

The sensory analysis by the taste panel was carried out in 14 sessions of tests. In each session 4 different random samples (legs) were presented to each taster. The sensory attributes evaluated in each sample were related to the appearance of the product (color, fat color, marbling and brightness), aroma (intensity, meat, acid, sweet, rancid, cured), taste (intensity, persistence, meat, rancid, salty, sweet, acid, cured) and texture (hardness, fibers feeling, and juiciness).

The place where the consumer test was conducted was properly prepared for consumers to evaluate the samples. Consumers in the common scope of the Polytechnic Institute of Bragança were randomly invited to participate in the panel. They had no training since the purpose of this test was precisely to simulate the real conditions of consumption but also the tests were performed in a controlled environment. The purpose of the work and questions related to completing the form were explained. Preference (hedonic) issues were applied, and consumers filled in a form that included the main attribute under study - global appreciation. A $10 \mathrm{~cm}$ unstructured scale with intervals $(0 \mathrm{~cm}$ - "extremely unpleasant" and $10 \mathrm{~cm}$ - "extremely pleasant") evaluating the aforementioned attributes was used. The test had a duration of about $5 \mathrm{~min}$ for each consumer, and 2 different samples were presented per person (sheep cured leg and goats cured leg), the tests were carried out in 4 different sessions (days) with a total of 100 consumers. Consumers were $56 \%$ male and $44 \%$ female and ranged between 18 and 67 years old.

\subsection{Statistical analysis}

Physicochemical data were analyzed using statistical package JMP ${ }^{\circledR}$ Pro 13.1.0 (2016) by Copyright@ 2016 SAS Institute Inc. Main effect specie (sheep and goat) was tested in mixed model as fixed effects (PROC MIXED, SAS) of treatment and the random effects of repeated measurement of individual leg sample in three replications. General mixed models procedure (PROC GLIMMIX, SAS) was used to find the probability of the difference as a result of specie. The predicted means obtained were ranked based on pair-wise least significance differences and compared using the $t$ Student test for $* 0.05, * * 0.01$ or ****0.001 significance levels.

Taste panel sensory data was submitted to Characterization of the Product procedure of the XLStat program, version 2016, an addition of the Microsoft Office Excel software (version 2010) to observe which
Table 1

Predicted values (means \pm standard error) of physical characteristics of sheep and goat cured legs at the three stages of curing process.

\begin{tabular}{|c|c|c|c|}
\hline & Goat & Sheep & $\mathrm{F}$ \\
\hline $\mathrm{pH}$ slaughter & $6.6 \pm 0.02$ & $6.7 \pm 0.02$ & $* *$ \\
\hline $\mathrm{pH}_{24 \mathrm{~h}}$ & $5.8 \pm 0.02$ & $5.7 \pm 0.01$ & $* *$ \\
\hline $\mathrm{pH}$ ripening & $5.8 \pm 0.03$ & $5.7 \pm 0.03$ & $* *$ \\
\hline$a_{w}$ slaughter & $0.98 \pm 0.01$ & $0.96 \pm 0.01$ & ns \\
\hline $\mathrm{a}_{\mathrm{w} \text { salting }}$ & $0.91 \pm 0.00$ & $0.91 \pm 0.00$ & ns \\
\hline $\mathrm{a}_{\mathrm{w} \text { ripening }}$ & $0.83 \pm 0.01_{a}$ & $0.87 \pm 0.01_{b}$ & $* * *$ \\
\hline Moisture (\%) & $36.7 \pm 0.57 \mathrm{a}$ & $36.9 \pm 0.57_{b}$ & $*$ \\
\hline $\mathrm{NaCl}(\%)$ & $3.8 \pm 0.23_{\mathrm{a}}$ & $4.7 \pm 0.24_{b}$ & $* * * *$ \\
\hline \multicolumn{4}{|l|}{ Color } \\
\hline$L^{*}$ slaughter & $35.14 \pm 0.30$ & $36.46 \pm 0.32$ & $* * *$ \\
\hline $\mathrm{L}^{*}$ salting & $30.36 \pm 0.33$ & $30.40 \pm 0.36$ & ns \\
\hline $\mathrm{L}^{*}$ ripening & $27.49 \pm 0.32$ & $27.83 \pm 0.39$ & ns \\
\hline $\mathrm{a}^{*}$ slaughter & $18.18 \pm 0.12$ & $20.01 \pm 0.14$ & $* * *$ \\
\hline $\mathrm{a}^{*}$ salting & $10.88 \pm 0.28$ & $11.58 \pm 0.30$ & ns \\
\hline$a^{*}$ ripening & $5.76 \pm 0.09$ & $5.82 \pm 0.29$ & ns \\
\hline $\mathrm{b}^{*}$ slaughter & $9.46 \pm 0.13$ & $9.89 \pm 0.09$ & $*$ \\
\hline $\mathrm{b}^{*}$ salting & $6.07 \pm 0.09$ & $6.06 \pm 0.09$ & ns \\
\hline $\mathrm{b}^{*}$ ripening & $5.72 \pm 0.07$ & $5.55 \pm 0.08$ & ns \\
\hline $\mathrm{H}^{*}$ slaughter & $27.04 \pm 0.24$ & $26.41 \pm 0.26$ & ns \\
\hline $\mathrm{H}^{*}$ salting & $32.93 \pm 0.53$ & $33.06 \pm 0.58$ & ns \\
\hline $\mathrm{H}^{*}$ ripening & $47.21 \pm 0.39 \mathrm{a}$ & $48.62 \pm 0.48_{b}$ & $*$ \\
\hline $\mathrm{C}^{*}$ slaughter & $20.68 \pm 0.15$ & $22.61 \pm 0.17$ & $* * *$ \\
\hline$C^{*}$ salting & $12.92 \pm 0.26$ & $13.70 \pm 0.28$ & $* * *$ \\
\hline $\mathrm{C}^{*}$ ripening & $8.33 \pm 0.10$ & $7.53 \pm 0.12$ & **** \\
\hline
\end{tabular}

Significance: ns: not significant; $\mathrm{a}_{\mathrm{W}}$ : water activity; $\mathrm{L}^{*}$ : brightness; $\mathrm{a}^{*}$ : redness; $\mathrm{b}^{*}$ : yellowness; $\mathrm{H}^{*}$ : Hue; $\mathrm{C}^{*}$ : Chroma.

$* P \leq 0.05$.

${ }^{* *} P \leq 0.01$.

${ }^{* * * *} P \leq 0.001$

sensory attributes better discriminate sheep and goats legs. This procedure gives us the main characteristics of each product. The output values obtained from the Characterization of the Product procedure are the results of the model used, $\mathrm{Y}=\mathrm{P}$ (product effect) $+\mathrm{J}$ (Judge effect), based on the work of Husson and Pagès (2003). Consumers' data was submitted to an analysis of variance (ANOVA), the effect of species, and consumers' sex, and age was tested. XLStat was also used in this statistical analysis.

\section{Results and discussion}

\subsection{Physicochemical characteristics}

The physical characteristics ( $\mathrm{pH}, \mathrm{a}_{\mathrm{w}}$, moisture and color coordinates and attributes) of sheep or goat cured legs are shown in Table 1.

The $\mathrm{pH}$ and aw are commonly accepted as important indicators of shelf life of cured products and according Matagaras et al. (2015) are decisive factors in the reduction of food-borne agents to achieve the microbiological stability of fermented products. There is a correct dropped in $\mathrm{pH}$ from 6.6-6.7 at slaughter to 5.7-5.8 at the kinetics of rigor mortis was completed. The $\mathrm{pH}$ value remained unchanged until the end of ripening process. Also the $\mathrm{a}_{\mathrm{w}}$ decreased successively from the slaughter to the salting and from there to the end of ripening period with $a_{w}$ values significantly different between sheep and goat, 0.87 and 0.83 respectively. The values found were similar to those found by several authors: for meat cured products from different species (Paleari, Moretti, Beretta, Mentasti, \& Bersani, 2003) including the goat bresaola although with an $\mathrm{pH}$ value higher (6.48); for smoked goat ham (Ivanovic, Nesic, Pisinov, \& Pavlovic, 2016); for goat and sheep meat cured mantas (Oliveira et al., 2014); as well for sheep and goat cured legs submitted at different ripenning periods (Tolentino et al., 2016) or also for beef cecina (Molinero et al., 2008). The $\mathrm{pH}$ and aw values found for us showed that could be an important role in controlling the meat spoiling promoting safety and shelf life stability of the products with respect to microbial growth. 
Ash content ranging 8-9\% is in the intervals found by other authors for cured products as Paleari et al. (2003) and Ivanovic et al. (2016). The ash content is much higher than that found by Oliveira et al. (2014) between 1 and $0.6 \%$ for sheep and goat "mantas", respectively. The difference is naturally explained by the different methodology used since the "blankets" correspond to the boned meat prior to the cured process while in cured legs the bone remain in the final product.

The moisture content ranging $36 \%$ was similar to the percentage found by Ivanovic et al. (2016) for the goat smoked ham and lower than the value found for goat bresaola (47.8\%) is relatively lower than the value found by Hierro et al. (2004) for goat cecina which was $64 \%$.

The sodium chloride content expressed in $\mathrm{NaCl} \%$ was significantly different $(P \leq 0.001) 3.8$ and $4.7 \%$ for goat and sheep ham, respectively and was similar to the content found by Ivanovic et al. (2016) for goat smoked ham (4.5\%). If we consider the amounts of salt in ham produced in the first half of the twentieth century $(>6 \%)$ (Lineback \& Stadler, 2009) the $4 \%$ of our products seem be acceptable. In any case with the modern tendency according to the aforementioned authors to produce today a ham with $<2 \%$ of amount of salt, the content of this curing agent in our products should be reduced in the trend to produce products containing less salt but without losses in food safety once the growth of some bacteria is inhibited by salt concentrations as low as $3 \%$ (Nummer \& Andress, 2002). In any case according Desmond (2006) before reduce the NaCl levels the microbiological shelf life and food safety of this processed products should be studied. Working with different ripening periods, Tolentino et al. (2016) have evaluated the microbiological quality of goat and sheep cured legs with $<4 \%$ of salt and concluded that safety indicators were absent in all the analyzed samples.

Table 1 also shows the color parameters assessed at slaughter, the end of salting period and the end of ripening process. The Hue $\left(\mathrm{H}^{*}\right)$ is the only attribute with no significant differences $(P \geq 0.05)$ between sheep and goat cured legs. All coordinates: lightness $\left(L^{*}\right)$, redness $\left(a^{*}\right)$ and yellowness $\left(\mathrm{b}^{*}\right)$ as well the coordinate Chroma $\left(\mathrm{C}^{*}\right)$ were significant different at different levels of significance. At the end of the salting period all parameters were equalized remaining the absence of significant differences between the two cured products until the end of ripening process with the exception of the $\mathrm{C}^{*}$ and $\mathrm{H}^{*}$. In the two products the $L^{*}, b^{*}$ and $a^{*}$ values decreased from the slaughter until the end of ripening period as was expected along the decrease of $a_{w}$ and as a result of salt action causing losses water and reduction of myoglobin concentrations. Similar situation was found by Ivanovic et al. (2016) evaluating the evolution of color of fresh goat meat to smoked ham. The low values of $b^{*}$ in our products compared with similar products from other species mainly pork ham could be due to the low fat level of goat and sheep cured legs, 6 and 7.9\% respectively as it was shown in Table 2. Anyway, all comparisons between different works for the variables and color coordinates by the CIELAB system must be made with due reservations that come from the different readings produced by different devices at different experimental conditions.

The high protein and low fat percentages of the goat and sheep cured legs is the main evidence of the effect of salting and ripening on the goat and sheep meat. The protein content more than doubled with the curing process. The higher protein and lower fat contents of goat legs is comparable to the values found by Paleari et al. (2003) to goat cured final product and to smoked goat ham by Ivanovic et al. (2016). The low cholesterol content is particularly evident in sheep cured legs and the cholesterol content of goat cured legs was comparable to that found for goat cured meat by Paleari et al. (2003). Goat cured legs showed higher collagen content than sheep cured legs, confirming the tendency reported by Schönfeldt et al. (1993) that goat meat tends to have more collagen content than sheep meat.

The fatty acid profile (only the most important with $>1 \mathrm{~g} / 100 \mathrm{~g}$ of fat) of the goat and sheep cured legs as raw and final products are shown in Table 3.

The amount of the major fatty acids of the final product were oleic acid (C18:1 n9c; 39.6 and $42.0 \mathrm{~g} / 100 \mathrm{~g}$ of fat, significant $P \leq 0.001$ different for goat and sheep cured legs, respectively), palmitic acid (C16:0; 23.7 and $23.2 \mathrm{~g} / 100 \mathrm{~g}$ of fat, for goat and sheep cured legs), stearic acid (C18:0; 18.8 and $17.0 \mathrm{~g} / 100 \mathrm{~g}$ of fat, for goat and sheep cured legs), linoleic acid (C18:2 n6c; 6.1 and $4.9 \mathrm{~g} / 100 \mathrm{~g}$ of fat, significant $P \leq 0.001$ different for goat and sheep cured legs, respectively) and arachidonic acid methyl ester (C20:4n6; 2.3 and $1.1 \mathrm{~g}$ of fat, significant $P \leq 0.001$ different for goat and sheep cured legs, respectively). Comparing the raw product with the final product there is a slight tendency for the increase of the long chain polyunsaturated fatty acids and a reducing of monounsaturated fat with de curing process. Overall the fatty acid profile found by us in the final product in its major component amounts coincides with that described by Ivanovic et al. (2016) for the goat's smoked ham and by Paleari, Moretti, Beretta, and Caprino (2008) for salted and ripened goat thigh as well as Paleari et al. (2003) for goat cured products or Villalobos-Delgado et al. (2014) for dry-cured lamb legs. As in our study also Ivanovic et al. (2016) found small amounts of elaidic acid (C18:1 n9t) but contrarily the cited authors we did not detect any amount of linoelaidic acid (C18:2n6t). Although the content of elaidic acid has doubled in goat legs and tripled in sheep legs with the curing process, the trans fatty acid (TFA) amount detected was much lower than the recommended energy intake for TFA by joint WHO/FAO expert consultation (Brouwer, 2016). No significant differences between goat and sheep cured legs were detected for the total amount of saturated fat (SFA) but while the amount of monounsaturated fat (MUFA) was significantly ( $P \leq 0.001$ ) higher for sheep cured legs the amount of polyunsaturated fat (PUFA) was significantly $(P \leq 0.001)$ higher for goats cured legs. The SFA content found $(45 \%)$ is lower than that observed for salted and ripened goat legs (49.8\%) by Paleari et al. (2008) but higher than the content found by VillalobosDelgado et al. (2014) for lamb cured legs (39.8\%). More over the MUFA percentage of goat cured legs $(44.19 \%)$ was higher than that found by Paleari et al. (2008) while the PUFA percentage was the same magnitude around $11 \%$. The MUFA and PUFA percentages of sheep cured legs 46.9 and 7.9 were quite different from the values found by VillalobosDelgado et al. (2014) for dry-cured lamb legs, 34.2 and 26\% for MUFA

Table 2

Predicted values (means \pm standard error) of protein collagen fat and cholesterol percentages of goat and sheep cured legs.

\begin{tabular}{|c|c|c|c|c|c|}
\hline & \multicolumn{2}{|l|}{ Goat } & \multicolumn{2}{|l|}{ Sheep } & \multirow[t]{2}{*}{$\mathrm{F}$} \\
\hline & Raw product & Final product & Raw product & Final product & \\
\hline Protein (\%) & $18.92 \pm 0.48_{c}$ & $46.2 \pm 0.51_{\mathrm{a}}$ & $18.16 \pm 0.08_{c}$ & $38.4 \pm 0.51_{b}$ & $* * *$ \\
\hline Collagen (\%) & $2.15 \pm 0.09 \mathrm{a}$ & $2.12 \pm 0.16_{\mathrm{a}}$ & $1.35 \pm 0.09_{\mathrm{b}}$ & $1.45 \pm 0.16_{\mathrm{b}}$ & $* *$ \\
\hline FAT (\%) & $5.33 \pm 0.40_{a}$ & $6.03 \pm 1.09_{\mathrm{ab}}$ & $8.70 \pm 0.40_{b}$ & $7.92 \pm 1.02_{b}$ & $*$ \\
\hline Cholesterol (\%) & na & $10.9 \pm 0.51_{\mathrm{a}}$ & na & $4.5 \pm 0.45_{b}$ & $* * *$ \\
\hline
\end{tabular}

Significance: ns: not significant; na: not available.

${ }^{*} P \leq 0.05$.

** $P \leq 0.01$.

**** $P \leq 0.001$. 
Table 3

Predicted values (means \pm standard error) of fatty acid profile (expressed in $\mathrm{g} / 100 \mathrm{~g}$ of fat) of goat and sheep cured legs.

\begin{tabular}{|c|c|c|c|c|c|}
\hline & \multicolumn{2}{|l|}{ Goat } & \multicolumn{2}{|l|}{ Sheep } & \multirow[t]{2}{*}{$\mathrm{F}$} \\
\hline & Raw product & Final product & Raw product & Final product & \\
\hline C $14: 0$ & $2.56 \pm 0.03$ & $2.19 \pm 0.06$ & $2.38 \pm 0.03$ & $2.11 \pm 0.05$ & ns \\
\hline C $16: 0$ & $24.21 \pm 0.1$ & $23.72 \pm 0.32$ & $22.70 \pm 0.15$ & $23.20 \pm 0.26$ & ns \\
\hline C $16: 1$ n7 & $2.57 \pm 0.1_{c}$ & $1.75 \pm 0.06_{\mathrm{a}}$ & $2.31 \pm 0.11_{\mathrm{d}}$ & $1.46 \pm 0.05_{b}$ & $* * * *$ \\
\hline C $17: 0$ & $1.21 \pm 0.01_{\mathrm{a}}$ & $1.13 \pm 0.03_{\mathrm{a}}$ & $1.34 \pm 0.01_{b}$ & $1.39 \pm 0.02_{\mathrm{b}}$ & $* * *$ \\
\hline C $18: 0$ & $18.97 \pm 0.21$ & $18.83 \pm 0.50$ & $18.50 \pm 0.21$ & $17.03 \pm 0.41$ & ns \\
\hline C18:1 n9t & $0.61 \pm 0.14_{c}$ & $1.88 \pm 0.09_{a}$ & $0.55 \pm 0.14_{c}$ & $2.54 \pm 0.07_{b}$ & $* * *$ \\
\hline C18:1 n9c & $38.91 \pm 0.29 a$ & $39.60 \pm 0.52_{\mathrm{a}}$ & $40.93 \pm 0.29_{b}$ & $42.02 \pm 0.42_{b}$ & **** \\
\hline $\mathrm{C} 18: 2 \mathrm{n} 6 \mathrm{C}$ & $3.74 \pm 0.46_{c}$ & $6.13 \pm 0.20_{\mathrm{a}}$ & $3.91 \pm 0.46_{c}$ & $4.88 \pm 0.17_{b}$ & $* * *$ \\
\hline C18:3 n3 & $0.52 \pm 0.02_{c}$ & $0.74 \pm 0.05_{a}$ & $0.76 \pm 0.02_{a}$ & $1.06 \pm 0.04_{b}$ & $* * *$ \\
\hline C20:4 n6 & $0.98 \pm 0.03_{c}$ & $2.27 \pm 0.12_{\mathrm{a}}$ & $0.49 \pm 0.03_{\mathrm{d}}$ & $1.05 \pm 0.09_{b}$ & **** \\
\hline SFA & $47.79 \pm 0.32 \mathrm{a}$ & $45.36 \pm 0.56_{b}$ & $45.82 \pm 0.32_{b}$ & $45.26 \pm 0.45_{b}$ & $*$ \\
\hline MUFA & $46.01 \pm 0.34_{b}$ & $44.19 \pm 0.52_{\mathrm{a}}$ & $48.23 \pm 0.34_{c}$ & $46.89 \pm 0.42_{\mathrm{b}}$ & $* * *$ \\
\hline PUFA & $6.20 \pm 0.47_{c}$ & $10.45 \pm 0.37 \mathrm{a}$ & $5.94 \pm 0.47_{c}$ & $7.85 \pm 0.30_{\mathrm{b}}$ & *** \\
\hline $\mathrm{P} / \mathrm{S}$ & $0.13 \pm 0.01_{c}$ & $0.23 \pm 0.009 a$ & $0.13 \pm 0.01_{c}$ & $0.17 \pm 0.008_{b}$ & $* * *$ \\
\hline PUFA-n3 & $1.08 \pm 0.08 \mathrm{a}$ & $1.78 \pm 0.09_{b}$ & $1.11 \pm 0.08_{a}$ & $1.68 \pm 0.07_{b}$ & $*$ \\
\hline PUFA-n6 & $5.12 \pm 0.12_{c}$ & $8.67 \pm 0.32_{a}$ & $4.83 \pm 0.12_{c}$ & $6.17 \pm 0.20_{\mathrm{b}}$ & $* * *$ \\
\hline PUFA-n6/n3 & $4.78 \pm 0.42_{a}$ & $4.96 \pm 0.18 \mathrm{a}$ & $4.38 \pm 0.42_{a}$ & $3.94 \pm 0.15_{b}$ & $* * *$ \\
\hline $\begin{array}{l}\text { TBARS } \\
\text { ( } \mathrm{mg} \text { of } \mathrm{m}\end{array}$ & & $0.48 . \pm 0.03$ & & $0.52 \pm 0.03$ & ns \\
\hline
\end{tabular}

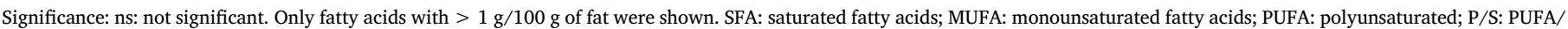

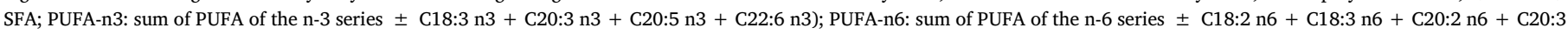
n6 + C20:4 n6); PUFA-n6/n3: ratio of PUFA n-6/PUFA n-3.

$* P \leq 0.05$.

**** $P \leq 0.001$.

and PUFA respectively. The differences can be explained by the types of animals of the two studies, which in the case of Villalobos were lambs with 6-8 week old whereas in our work they were culled ewes with $>8$ years old.

The ratios PUFA/SFA (P/S) and n-6/n-3 are widely used for several food and nutritional organizations to evaluate the nutritional value of fat in human diet and to make food recommendations. The curing process produced a slight increase in the $\mathrm{P} / \mathrm{S}$ ratio but the values found 0.23 and 0.17 for goat and sheep cured legs, respectively were within the recommended limits and according to Wood et al. (2008) within the ratio guide-lines recommended above $0.4-0.5$. Similar ratios were found by Paleari et al. (2008) and Ivanovic et al. (2016) for salted and ripened goat thigh $(0.22)$ and goat smoked ham $(0.25)$. Even though there is no compelling scientific rationale for the recommendation of a specific ratio of $n-6$ to $n-3$ fatty acids (WHO, 2008) the ratio observed was 4.96 and 3.94 for goat and sheep cured legs, respectively in the limit, which not should exceed 4 according to Simopoulos (2004).

The degree of oxidation at the end of cured process was assessed by TBARs measurement and is shown in Table 3 as malonaldehyde (MDA) synthetized during the oxidation expressed in $\mathrm{mg}$ MDA)/ $\mathrm{kg}$ of meat. TBARS values in goat and sheep cured legs were not significant different and are much lower than the value of $2 \mathrm{mg}$ of MDA/Kg which is the upper limit of rancidity indicated by Campo et al. (2006) for consumer acceptability. The values found by us were also lower than the values observed by Oliveira et al. (2014) for salted and ripened sheep and goat meats (Mantas) 2.16 and $1.87 \mathrm{mg} \mathrm{MDA} / \mathrm{Kg}$, respectively and the values for goat and sheep dried meat 4.44 and $2.59 \mathrm{mg} \mathrm{MDA} / \mathrm{Kg}$, respectively accounted by Dorj, Tsagaan, and Sekikawa (2015). Close to the values found by us are the values of other similar meat pork cured products as dry-cured Celta ham by Bermúdez, Franco, Carballo, and Lorenzo (2014) or the dry-cured lacón by Lorenzo, Cittadini, Bermúdez, and Munekata (2015). Nevertheless the lipid oxidation threshold of $2 \mathrm{mg} / \mathrm{kg}$ proposed by Campo et al. (2006) is not a real detection or acceptability limit. According to Ripoll, Joy, and Muñoz (2011) an acceptability limit of $1 \mathrm{mg}$ MDA/ $\mathrm{kg}$ seems to be more suitable for meat lamb than those higher limits considered for beef. Studying the effect of cooling temperature on the quality on lamb Muela, Sañudo, Campo, Medel, and Beltrán (2010) found low levels of TBARS between 0.127 and 0.139.

\subsection{Sensory analysis}

The taste panel was able to observe significant differences between the species, sheep and goats, according to the attributes used for the product characterization. The attributes in study refer to appearance, aroma, flavor and texture.

In Table 4, is shown the discriminatory power of each attribute evaluated by the taste panel, where the $p$-value indicates the degree of significance (discriminatory power) of the attribute when comparing the two species.

The lower $p$-value, the greater the discriminatory power of the evaluated attributes. Thus, the attribute that discriminates the best among the evaluated products is the hardness, followed by juiciness,

Table 4

Discriminatory power of sensory descriptors and adjusted means \pm standard error for sheep and goats cured legs.

\begin{tabular}{llll}
\hline Descriptors & $p$-Value & Sheep & Goats \\
\hline Meat color & 0.1462 & $6.46 \pm 0.141$ & $6.66 \pm 0.109$ \\
Fat color & 0.5442 & $4.84 \pm 0.168$ & $4.92 \pm 0.155$ \\
Marbling & 0.8233 & $2.81 \pm 0.101$ & $2.79 \pm 0.092$ \\
Brightness & $<0.0001$ & $2.81 \pm 0.102$ & $2.43 \pm 0.076$ \\
Aroma intensity & 0.5572 & $5.52 \pm 0.122$ & $5.46 \pm 0.113$ \\
Aroma species meat & 0.0018 & $3.42 \pm 0.142$ & $3.11 \pm 0.128$ \\
Aroma rancid & 0.1221 & $1.87 \pm 0.104$ & $1.76 \pm 0.086$ \\
Aroma acid & 0.1288 & $2.50 \pm 0.114$ & $2.66 \pm 0.109$ \\
Aroma sweet & 0.3572 & $2.63 \pm 0.110$ & $2.53 \pm 0.102$ \\
Aroma cured & 0.0383 & $4.63 \pm 0.109$ & $4.84 \pm 0.104$ \\
Taste intensity & 0.2290 & $5.90 \pm 0.119$ & $5.79 \pm 0.121$ \\
Taste persistence & 0.0238 & $5.57 \pm 0.124$ & $5.32 \pm 0.129$ \\
Taste species meat & $<0.0001$ & $4.02 \pm 0.155$ & $3.51 \pm 0.141$ \\
Taste cured & 0.0190 & $4.69 \pm 0.126$ & $4.95 \pm 0.126$ \\
Taste rancid & 0.1529 & $2.05 \pm 0.119$ & $1.92 \pm 0.104$ \\
Taste salty & 0.0374 & $4.64 \pm 0.133$ & $4.41 \pm 0.117$ \\
Taste sweet & 0.3933 & $2.55 \pm 0.123$ & $2.46 \pm 0.111$ \\
Taste acid & 0.8924 & $2.67 \pm 0.117$ & $2.69 \pm 0.113$ \\
Texture hardness & $<0.0001$ & $2.79 \pm 0.123$ & $3.89 \pm 0.130$ \\
Texture fibers feeling & $<0.0001$ & $2.90 \pm 0.122$ & $3.69 \pm 0.131$ \\
Texture adhesiveness & $<0.0001$ & $3.72 \pm 0.141$ & $3.05 \pm 0.121$ \\
Texture juiciness & $<0.0001$ & $4.97 \pm 0.128$ & $4.05 \pm 0.126$ \\
\hline & & & \\
\hline
\end{tabular}


adhesiveness and fibers feeling ( $P \leq 0.001)$, all texture attributes, and the least discriminating between one product and another is the acid taste, aroma intensity and marbling $(P>0.05)$. These results are in accordance with Tolentino et al. (2016) that also found that sheep and goats cured legs were better discriminated by texture attributes.

Table 4 also presents the adjusted mean \pm standard error of the goats and sheep cured legs sensory attributes.

The attribute that stands out with respect to the appearance is undoubtedly the brightness, which was considered significantly $(p<0.0001)$ higher for sheep than for goat. The other attributes (meat and fat color, and marbling) were not significantly different $(P>0.05)$ for sheep or goats. Brightness was also a highly significant discriminant attribute between sheep and goats cured legs in Tolentino et al. (2016) work.

The species meat and cured aromas discriminate sheep and goats legs. The values for the meat aroma were 3.42 and 3.11 , in sheep and goats, respectively. Cured aroma was significantly $(P \leq 0.05)$ higher in goats, with averages of 4.84 and 4.63 in goats and sheep, respectively.

Taste attributes discriminate sheep and goats legs. Significant $(P<0.05)$ differences were found on taste persistence, species meat, cured, and salty taste. Taste persistence, species meat and salty taste were higher in sheep legs. Goats' legs had higher cured taste. The other taste attributes were not significantly different $(P>0.05)$.

All texture attributes were significantly $(P \leq 0.001)$ different. Apparently related, hardness and fibers feeling are higher in goats, with adjusted averages of 3.89 and 3.69, respectively, contrasting with values of 2.79 and 2.90 for sheep legs. The adhesiveness and juiciness were higher for sheep, considered by the taste panel to be a more adhesive and juicier product, having averages of 3.72 and 4.97, respectively. Generally, our results confirm the ones obtained by Tolentino et al. (2016) concerning texture attributes. Also, Paulos et al. (2015) found goat meat fresh sausages were harder and more fibrous than sheep's.

The overall acceptability of the sheep and goats cured legs by the consumer panel indicated a high acceptability in both cases without significant differences $(P>0.05)$ between them in agreement with Paulos et al. (2015) when studying sheep and goat meat fresh sausages. When asked: "Would you be willing to buy this product on the market?" $100 \%$ acceptance was obtained, showing that there is a consumer market for both products. Comparing the averages of the evaluated products even without significant differences, it is possible to verify that the sheep cured legs were better evaluated than those of goats (7.4 \pm 0.48 and $7.0 \pm 0.48$, for sheep and goats legs mean \pm standard error evaluation, respectively). It is worth mentioning that the averages obtained for both species are considered very good.

The consumers' sex and age were also evaluated in order to verify if any of these factors could influence the consumer to prefer a particular product. No significant differences were found.

\section{Conclusions}

The $\mathrm{pH}(5.7-5.8)$ and aw (0.87 and 0.83) values found showed that the goat and sheep cured legs could be a food safety product with shelf life stability in relation to microbial growth. The high protein ( 46.2 and $38.4 \%$ ) and low fat (5.3 and $8.7 \%$ ) percentages show that the effect of salting and ripening processes makes the goat and sheep cured legs an interesting and nutritionally balanced meat product with a low cholesterol content and PUFA/SFA (P/S) and $n-6 / n-3$ ratios within the guide-lines recommended by the several world food organizations.

Taking into account the physicochemical and sensory characteristics the goat and sheep cured legs produced from cull animals could be an interesting way to give added value to animals with very low commercial price.

\section{Acknowledgements}

Work included in the Portuguese PRODER research Project number 020260013013 "New goat and sheep processed meat products" BISOVICAP - Processing meat from pigs, sheep and goats, to produce new products. Ham and pâté, Project PROTEC, SI I \& DT - Projects in Co-Promotion, $\mathrm{n}^{\circ}$ 21511. The authors are grateful to Laboratory of Carcass and Meat Quality of Agriculture School of Polytechnic Institute of Bragança 'Cantinho do Alfredo'. The authors are members of the MARCARNE network, funded by CYTED (ref. 116RT0503).

\section{References}

AOAC (1990). AOAC official methods of analysis (15th ed.). Washington, DC: Association of Official Analytical Chemists (1990).

Bermúdez, R., Franco, D., Carballo, J., \& Lorenzo, J. M. (2014). Physicochemical changes during manufacture and final sensory characteristics of dry-cured Celta ham. Effect of muscle type. Food Control, 43, 263-269.

Brouwer, I. A. (2016). Effect of trans-fatty acid intake on blood lipids and lipoproteins: A systematic review and meta-regression analysis. Geneva: World Health Organization, 2016.

Campo, M. M., Nute, G. R., Hughes, S. I., Enser, M., Wood, J. D., \& Richardson, R. I. (2006). Flavour perception of oxidation in beef. Meat Science, 72, 303-311.

Commission Internationale de l'Eclairage (CIE). (1986). ColorimetryPublication CIE No. 15.2(2nd ed.). Vienna: Commission Internationale de l'Eclairage.

Das, A. K., Anjaneyulu, A. S. R., Thomas, R., \& Kondaiah, N. (2009). Effect of different fats on the quality of goat meat patties incorporated with full-fat soy paste. Journal of Muscle Foods, 20(1), 37-53.

Desmond, E. (2006). Reducing salt: A challenge for the meat industry. Meat Science, 74(2006), 188-196.

Domínguez, R., Borrajo, P., \& Lorenzo, J. M. (2015a). The effect of cooking methods on nutritional value of foal meat. Journal of Food Composition and Analysis, 43, 61-67.

Domínguez, R., Crescente, S., Borrajo, P., Agregan, R., \& Lorenzo, J. M. (2015b). Effect of slaughter age on foal carcass traits and meat quality. Animal, 9(10), 1713-1720.

Dorj, S., Tsagaan, A., \& Sekikawa, M. (2015). Quality of dried meats from different livestock species. The Journal of Agricultural Science, 15(02), 3-9.

Folch, J., Lees, M., \& Stanley, G. H. S. (1957). A simple method for isolation and purification of total lipids from animal tissues. Journal of Biological Chemistry, 226, 497-509.

Fratianni, F., Sada, A., Orlando, P., \& Nazzaro, F. (2008). Micro-Electrophoretiv study of the sarcoplasmic fraction in dry-cured goat raw ham. The Open Food Science Journal, 2, 89-94.

Hierro, E., de la Hoz, L., \& Ordoñez, J. A. (2004). Headspace volatile compounds from salted and occasionally smoked dried meats (cecinas) as affected by animal species. Food Chemistry, 85, 649-657.

Husson, F., \& Pagès, J. (2003). Comparison of sensory profiles done by trained and untrained juries: Methodology and results. Journal of Sensory Studies, 18(6), 453-464.

Ivanovic, S., Nesic, K., Pisinov, B., \& Pavlovic, I. (2016). The impact of diet on the quality of fresh meat and smoked ham in goat. Small Ruminant Research, 138, 53-59.

Leite, A., Rodrigues, S., Pereira, E., Paulos, K., Oliveira, A. F., Lorenzo, J. M., \& Teixeira, A. (2015). Physicochemical properties, fatty acid profile and sensory characteristics of sheep and goat meat sausages manufactured with different pork fat levels. Meat Science, 105, 114-120.

Lineback, D. R. \& Stadler, R. H. (2009). Introduction to food process toxicants. In D. R. Lineback, \& R. H. Stadler (Eds.), Process-induced food toxicants (pp. 3-21). Wiley 2009.

Lorenzo, J. M., Cittadini, A., Bermúdez, R., \& Munekata, P. E. (2015). Influence of partial replacement of $\mathrm{NaCl}$ with $\mathrm{KCl}, \mathrm{Cacl} 2$ and $\mathrm{MgCl} 2$ on proteolysis, lipolysis and sensory properties during the manufacture of dry-cured lavon. Food Control, 55, 90-96.

Madruga, M. S., \& Bressan, M. C. (2011). Goat meats: Description, rational use, certification, processing and technological developments. Small Ruminant Research, 98, $39-45$.

Matagaras, M., Bellio, A., Rovetto, F., Astegiano, S., Decastelli, L., \& Cocolin, L. (2015). Risk-based controlo f food-borne pathogens Listeria monocytogenes and Salmonella mesenteroides in Italian fermented sausages Caccitore and Felino. Meat Science, 103, $39-45$.

Molinero, C., Martínez, B., Rubio, B., González-Fernández, C., Garcia-Cachán, M. D., .. Jaime, I. (2008). The anatomical origin of raw meat affects the sensory and chemical characteristics of a dry cured beef product: Cecina de Leon. Food Science and Technology International, 14(3), 225-232.

Muela, E., Sañudo, C., Campo, M. M., Medel, I., \& Beltrán, J. A. (2010). Effects of cooling temperature and hot carcass weight on the quality of lamb. Meat Science, 84(1), $101-107$.

NP 1612 (2002). Portuguese norm-meat and meat products. Determination of total nitrogen content. Reference method. Caparica, Portugal: Portuguese Institute of Quality, Ministry of Economy and Innovation (ISO 937:1978).

NP 1614 (2002). Portuguese Norm-Meat and meat products. Determination of moisture content. Reference method. Caparica, Portugal: Portuguese Institute of Quality, Ministry of Economy and Innovation (ISO 1442:1197). 
NP 1845 (1982). Portuguese standard-meat, meat products and derivatives. Determination of chloride content. Current method. Caparica, Portugal: Portuguese Institute of Quality, Ministry of Economy and Innovation.

NP 1987 (2002). Portuguese norm-meat and meat products. Determination of hydroxyproline content. Reference method. Caparica, Portugal: Portuguese Institute of Quality, Ministry of Economy and Innovation (ISO 3496:1994).

NP 3356. (2009). Portuguese norm-fish and agriculture products. Thiobarbituric acid determination. Spectrophotometric method. Caparica, Portugal: Portuguese Institute of Quality, Ministry of Economy and Innovation.

NP 8586-1 (2001). Portuguese norm-sensory analysis. General guidance of the selection, training and monitoring of assessors. Part 1: selected assessors. Caparica, Portugal: Portuguese Institute of Quality, Ministry of Economy and Innovation (ISO 85861:1993).

NP-ISO-3441 (2008). Determinação do pH. Método de referência. Caparica, Portugal: Portuguese Institute of Quality, Ministry of Economy and Innovation.

Nummer, B. A., \& Andress, E. L. (2002). Curing and smoking meats for home food preservation. literature review and critical preservation points. Athens, GA: The University of Georgia, Cooperative Extension Service. Retrieved "X date" from: http://nchfp.uga. edu/publications/nchfp/lit_rev/cure_smoke_rev.html.

Oliveira, A. F., Rodrigues, S., Leite, A., Paulos, K., Pereira, E., \& Teixeira, A. (2014). Short communication: Quality of ewe and goat meat cured product mantas. An approach to provide value added to culled animals. Canadian Journal of Animal Science, 94(3), 459-462.

Paleari, M. A., Moretti, V. M., Beretta, G., Mentasti, T., \& Bersani, C. (2003). Cured products from different animal species. Meat Science, 63, 485-489.

Paleari, M. A., Moretti, V. M., Beretta, G., \& Caprino, F. (2008). Chemical parameters, fatty acids and volatile compounds of salted and ripened goat thigh. Small Ruminant Research, 74, 140-148.

Paulos, K., Rodrigues, S., Oliveira, A. F., Leite, A., Pereira, E., \& Teixeira, A. (2015). Sensory characterization and consumer preference mapping of fresh sausages manufactured with goat and sheep meat. The Journal of Food Science, 80(Nr. 7), S1568-S1573.

Polpara, Y., Sornprasitt, T., \& Wattanachant, S. (2008). Quality characteristics of raw and canned goat meat in water, brine, oil and Thai curry during storage. Journal of Science and Technology, 30(Suppl. 1), 41-50.

Ripoll, G., Joy, M., \& Muñoz, F. (2011). Use of dietary vitamin E and selenium (Se) to increase the shelf life of modified atmosphere packaged light lamb meat. Meat Science, 87(1), 88-93.

Schönfeldt, H. C., Naude, R. T., Bok, W., vanHeerden, S. M., Swoden, L., \& Boshoff, E. (1993). Cooking and juiciness related quality characteristics of goat and sheep meat. Meat Science, 34, 381-394.

Simopoulos, A. P. (2004). Omega-6/omega-3 essential fatty acid ratio and chronic diseases. Food Reviews International, 20(1), 77-90.

Statistical Analysis Systems (2016). JMP ${ }^{\oplus}$ Pro 13.1. Cary, NC, USA: Statistical Analysis Systems, Institute Inc.

Teixeira, A., Pereira, E., \& Rodrigues, E. S. (2011). Goat meat quality. Effects of salting, air-drying and ageing processes. Small Ruminant Research, 98, 55-58.

Tolentino, G. S., Estevinho, L. M., Pascoal, A., Rodrigues, S. S., \& Teixeira, A. J. (2016) Microbiological quality and sensory evaluation of new cured products obtained from sheep and goat meat. Animal Production Science, 57, 391-400.

Villalobos-Delgado, L., Caro, I., Blanco, C., Morán, L., Prieto, N., Bodas, R., .. Mateo, J. (2014). Quality characteristics of a dry-cured lamb leg as affected by tumbling after dry-salting and processing time. Meat Science, 97, 115-122.

Wood, J. D., Enser, M., Fisher, A. V., Nute, G. R., Sheard, P. R., Richardson, R. I., .. Whittington, F. M. (2008). Fat deposition, fatty acid composition and meat quality: A review. Meat Science, 78, 343-358.

World Health Organization (WHO). (2008). Interim summary of conclusions and dietary recommendations on total fat \& fatty acids. From the joint FAO/WHO expert consultation on fats and fatty acids in human nutrition, 10-14 November, 2008. Geneva: WHO. 